\title{
Current status of the application of gene editing in pigs
}

\author{
Fuminori TANIHARA ${ }^{1,2)}$, Maki HIRATA ${ }^{1)}$ and Takeshige OTOI ${ }^{1)}$ \\ 1) Faculty of Bioscience and Bioindustry, Tokushima University, Tokushima 770-8513, Japan \\ ${ }^{2)}$ Center for Development of Advanced Medical Technology, Jichi Medical University, Tochigi 329-0498, Japan
}

\begin{abstract}
Genetically modified animals, especially rodents, are widely used in biomedical research. However, non-rodent models are required for efficient translational medicine and preclinical studies. Owing to the similarity in the physiological traits of pigs and humans, genetically modified pigs may be a valuable resource for biomedical research. Somatic cell nuclear transfer (SCNT) using genetically modified somatic cells has been the primary method for the generation of genetically modified pigs. However, site-specific gene modification in porcine cells is inefficient and requires laborious and timeconsuming processes. Recent improvements in gene-editing systems, such as zinc finger nucleases, transcription activator-like effector nucleases, and the clustered regularly interspaced short palindromic repeats (CRISPR)/CRISPR-associated protein (CRISPR/Cas) system, represent major advances. The efficient introduction of site-specific modifications into cells via gene editors dramatically reduces the effort and time required to generate genetically modified pigs. Furthermore, gene editors enable direct gene modification during embryogenesis, bypassing the SCNT procedure. The application of gene editors has progressively expanded, and a range of strategies is now available for porcine gene engineering. This review provides an overview of approaches for the generation of genetically modified pigs using gene editors, and highlights the current trends, as well as the limitations, of gene editing in pigs.
\end{abstract}

Key words: Clustered regularly interspaced short palindromic repeats (CRISPR)/CRISPR-associated protein (CRISPR/Cas), Gene editing, Pig, Transcription activator-like effector nuclease (TALEN), Zinc finger nuclease (ZFN)

(J. Reprod. Dev. 67: 177-187, 2021)

\section{Introduction}

Genetically modified animals, especially rodents, are widely used as biomodels to elucidate animal physiology and disease mechanisms, including human traits and diseases. However, for efficient translational and preclinical studies, additional insights from non-rodent animal models are important [1]. Pigs are similar to humans in several respects, particularly in anatomy and physiology. Additionally, they breed year-round with large litter sizes. As pigs are considered an excellent animal model, gene modification is expected to improve the value of pig resources for biomedical research. The first transgenic pig, reported in 1985 [2], was produced by microinjection of exogenous DNA into the pronuclei of porcine zygotes through a fine glass needle. Subsequently, pronuclear injection has been used to establish genetically modified pig lines $[3,4]$. This technique is simple but requires technical proficiency. Furthermore, the low efficiency of generating founder pigs carrying mutations and the random integration of injected DNA into the genome without control of the copy number result in unstable phenotypes, gene silencing, and unpredictable gene expression, thereby limiting the application

Received: February 19, 2021

Accepted: March 20, 2021

Advanced Epub: April 10, 2021

(C2021 by the Society for Reproduction and Development

Correspondence: F Tanihara (e-mail: f_tanihara@jichi.ac.jp)

This is an open-access article distributed under the terms of the Creative Commons Attribution Non-Commercial No Derivatives (by-nc-nd) License. (CC-BY-NC-ND 4.0: https://creativecommons.org/licenses/by-nc-nd/4.0/) of such mutant pigs.

In mice, the establishment of embryonic stem cells (ESCs) promoted the development of genetically modified animals owing to the production of chimeras with germline transmission, which represents a significant advance in biomedical research. However, for pigs, stem cell lines, including ESCs, which contribute to the germline, are not available [5]. Since somatic cell nuclear transfer (SCNT) has been established in pigs [6-8], SCNT using genetically modified somatic cells as nuclear donors has been widely chosen as a method for the generation of genetically modified pigs. The correct use of somatic cells carrying the desired mutation, including multiple gene modifications, as nuclear donors virtually ensures that pigs will carry the desired mutations and the appropriate number of copies of the transgene. Furthermore, direct gene editing during embryogenesis often induces genetic mosaicism, which complicates the phenotypic analysis of founders, whereas SCNT can ensure non-mosaic genotypes in the resulting pigs. These characteristics, which have significant advantages, show that SCNT can be used as a primary method for the generation of genetically modified pigs.

SCNT overcomes the low efficiency and random transmission of gene modifications in delivered piglets that characterize pronuclear microinjection. However, site-specific gene insertion in porcine cells is limited by the low efficiency of homologous recombination (HR) and the sophisticated selection processes within cells following gene modification procedures, necessitating laborious and time-consuming processes [9]. Recently developed precise nuclease-mediated gene editing systems have dramatically improved gene modification in pigs. This review describes the production of genetically modified 
pigs using gene editors, provides an overview of approaches for the generation of genetically modified pigs using various types of gene editors, and highlights current trends, including the establishment of disease models and research on pig-to-human transplantation, as well as the limitations of gene editing in pigs.

\section{Gene Editors: Improvements in Engineered Endonucleases}

Engineered endonucleases, including artificial nucleases, such as zinc finger nucleases (ZFNs) $[10,11]$ and transcription activatorlike effector nucleases (TALENs) [12], as well as RNA-guided endonucleases, such as the clustered regularly interspaced short palindromic repeats (CRISPR)/CRISPR-associated protein (CRISPR/ Cas) system [13, 14], are major innovations for gene modification in somatic cells, stem cells, and zygotes/embryos of various animal species. These nucleases have precise DNA-binding ability and generate double-strand breaks (DSBs) at the desired genomic locus. DSBs trigger endogenous DNA repair via non-homologous end-joining (NHEJ) or homology-directed repair (HDR) pathways [15]. NHEJ occurs when the ends of a DSB are rejoined without any DNA template to guide this repair. Successfully repaired targeted sequences are repeatedly cut by gene editors, resulting in the frequent introduction of short DNA insertions/deletions (indels). These indels create targeted gene knockouts by inducing a frameshift in the codons, which is followed by the formation of a premature termination codon [12]. HDR relies on donor DNA with homologous arms from sister chromatids, homologous chromosomes, exogenous DNA templates, or single-strand donor oligonucleotides (ssODNs), and enables gene knock-in and the introduction of the desired point mutation. In general, the frequency of HDR is lower than that of NHEJ in most cell types [16].

ZFNs are gene editors composed of DNA-binding domains (zinc finger proteins) and a DNA-cutting domain (the chimeric restriction nuclease $F o k I$ ) acting as a heterodimer. Zinc finger domains recognize specific sequences in genomic DNA, after which FokI nuclease and the zinc finger protein induce DSBs at the targeted position. However, the practical use of ZFNs in laboratories is hindered by high costs and technical difficulties [17]. TALENs are conceptually similar to ZFNs. Transcription activator-like effectors (TALEs) are naturally occurring proteins found in the plant pathogenic bacterial genus Xanthomonas. TALENs have a TALE as the DNA-binding domain and FokI as the cleavage domain. The preparation of TALENs is simpler than that of ZFNs; therefore, they are preferred in laboratory settings for gene editing.

ZFNs and TALENs are artificial nucleases. In contrast, CRISPR/ Cas9 is an RNA-guided endonuclease that is derived from an adaptive bacterial immune system component $[13,14,18]$. The CRISPR/Cas9 system comprises a guide RNA (gRNA) and Cas9 nuclease. Since the first practical demonstration of gene editing using the CRISPR/Cas9 system in 2013, the system has been dramatically improved. Various gRNA/Cas9-related expression plasmids, Cas9 proteins, tools for gRNA design, and subsequent gRNA order/purchase systems are now available [19]. The system does not require specialized methodology or equipment; this has contributed to its recent widespread use.

Off-target effects, which are unexpected DNA cleavages caused by the binding of gene editors to unintended genomic sites, are of major concern in gene editing, especially using the CRISPR/Cas9 system; these have limited the research and clinical applications of gene editors [20, 21]. Carey et al. highlighted the frequency of off-target events induced by cytoplasmic microinjection of CRISPR/Cas9 during embryogenesis [22]; they detected off-target cleavage, but concluded that the frequency was low. Zhou et al. also detected off-target events induced by cytoplasmic microinjection of CRISPR/Cas9 [23]. Other off-target events were observed during SCNT-mediated production of gene-edited pigs using a ZFN [24] and CRISPR/Cas9 [25, 26], but mutations were only observed in non-coding regions in two out of the three studies $[24,26]$. To the best of our knowledge, off-target events in gene-edited offspring have not been detected in any other study. Choi et al. showed that there was no off-target cleavage in offspring when using whole-genome sequencing [27]. To date, off-target events have not produced any critical problems in geneedited porcine offspring. Various approaches have been developed to minimize these off-target effects, such as off-target detection by algorithmically designed software and genome-wide assays, the use of cytosine or adenine base editors, prime editing, and the chemical modification of gRNA [19, 28]. Furthermore, Cas9 variants such as Cas9 nickase [29], which cleaves only the target strand (by double nicking), and catalytically dead Cas9 combined with FokI nuclease (FokI-dCas9) [30, 31], reduce off-target events. Variants suggested by structural studies of Cas9, such as Cas9-HF1 [32], evo-Cas9 [33], eSpCas9 [34], and Hypa-Cas9 [35], also improve gene editing efficiency and discrimination against off-target events. The careful design of binding modules or gRNAs and improved application methods will minimize off-target effects in founder generations and reduce the labor required to analyze off-target candidates.

\section{Methods for Generation of Genetically Modified Pigs Using Gene Editors}

The ZFN, TALEN, and CRISPR/Cas9 systems enable efficient gene targeting and the introduction of multiallelic modifications into somatic cells, simplifying the preparation of donor cells for SCNT in pigs. Furthermore, gene editors have enabled the direct modification of genomic DNA in zygotes/embryos using cytoplasmic microinjection and electroporation (Fig. 1).

\section{SCNT using gene-edited somatic cells}

Gene editors enable the one-step knockout of genes in somatic cells without any marker or exogenous DNA fragments. Such gene-edited cells have accelerated SCNT-mediated production of genetically modified pigs. Gene editors also facilitate multiple gene editing and knock-in of exogenous genes; hence, double- [36-38], triple- [39-41], and quadruple-gene-edited pigs [42] and knock-in pigs [43, 44] have been generated using the SCNT technique. Following appropriate selection of donor cells after gene editing, the delivered piglets carry the desired genotypes. Furthermore, SCNT does not result in mosaicism, which is observed in gene-editor-mediated direct gene modification during embryogenesis, and thus aids in the phenotypic analysis of founder pigs. SCNT is the primary method for generating gene-edited pigs. However, offspring derived from reconstructed embryos often show abnormalities, such as birth defects, abortions, 
Somatic cell nuclear transfer (SCNT)
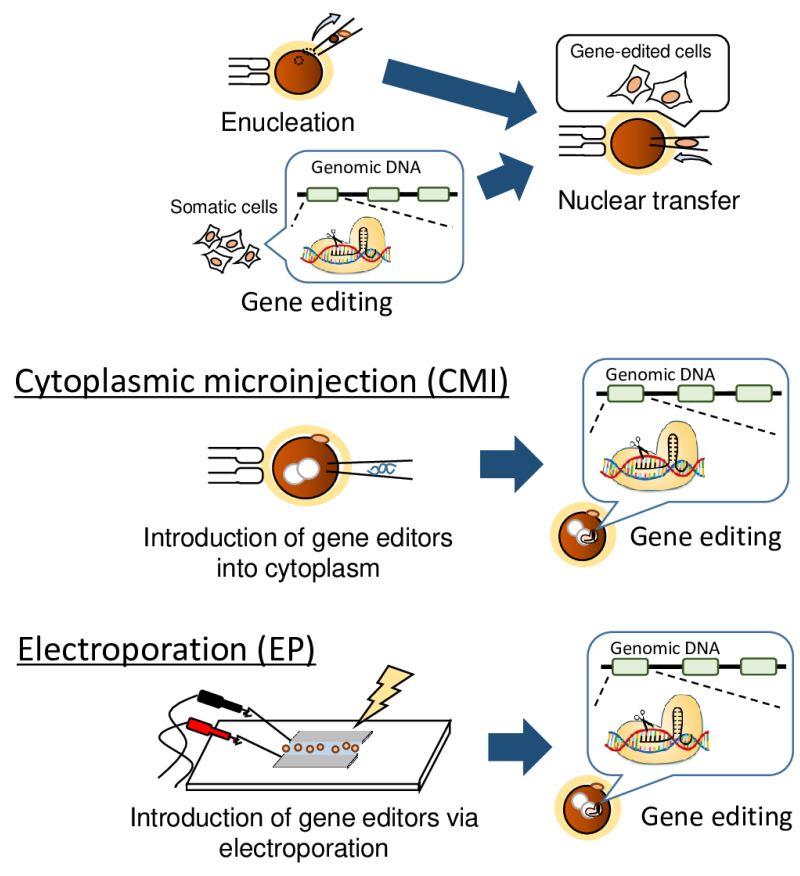

Fig. 1. Schematic of major methods for generating genetically modified pigs using gene editors.

and early postnatal death; this is a limitation of SCNT [45].

\section{Direct introduction of gene editors during embryogenesis}

Microinjection of gene editors into zygotes/embryos: The direct introduction of gene editors into the cytoplasm, an alternative to SCNT, simplifies the genetic modification of fertilized zygotes/embryos. Porcine oocytes have high lipid contents; therefore, centrifugation is required to visualize the pronuclei for successful pronuclear injection at the zygote stage. However, gene editors are generally supplied with nuclear localization signals, making the centrifugation procedure and maneuvering of the glass needle toward the pronuclei unnecessary. Cytoplasmic microinjection-mediated gene-edited pigs have been produced using gene editors in the early stages of their development [46-48]. Microinjection also enables the introduction of large molecules; therefore, microinjection-mediated knock-in pigs can be established [49]. An advantage of microinjection-mediated gene editing is the high viability of the manipulated zygotes/embryos. After the transfer of microinjected zygotes/embryos, the litters obtained from manipulated embryos tend to be larger than those from embryos generated by SCNT [50]. Although the results of embryo transfer depend on the condition of the recipient surrogates and operator skill in embryonic manipulation, the high viability of the zygotes/embryos and resulting piglets reduces labor.

Delivery of CRISPR/Cas9 system via electroporation during embryogenesis: Electroporation-mediated gene editing is a micromanipulation-free method in which large numbers of gene-edited zygotes/embryos can be prepared by introducing gene editors into zygotes. In mice, electroporation is widely used to introduce gene editors [51]. Gene editing via electroporation has also been applied to porcine zygotes [52], with successful gene modification (knockout) [52-55]. Electroporation-mediated gene editing requires no specialized equipment and benefits from a simple process and high zygote viability. However, the introduction of large molecules, including transgenes for knock-in, by electroporation alone is difficult in pigs. Generally, the molecular uptake into cells via electroporation is proportional to the field strength, pulse length, and number of pulses used. Porcine in vitro-fertilized zygotes/embryos are sensitive to electricity, and high voltages are harmful, unlike in mice $[52,56]$. Hence, a knock-in system for large transgenes via electroporation has not been established. Further research focusing on electroporationmediated gene editing and the proper choice of electroporation and cytoplasmic microinjection techniques (depending on the study purpose and type of mutation) is needed.

\section{Recent Trends in Gene Editing in Pigs}

Gene editors have been used to generate genetically modified pigs. In 2011, fifteen years after the initial report of the concept of ZFNs [10], genetically edited pigs were generated using them [24, $57,58]$. TALEN and the CRISPR/Cas9 system were also applied to generate genetically modified pigs soon after practical gene editing in mammalian cells was demonstrated. The low-density lipoprotein receptor $(L D L R)$-knockout pigs reported in 2012 were the first to be generated using a TALEN [59]. Using the CRISPR/Cas9 system, Whitworth et al. generated CD163- and CD1D-modified pigs using SCNT and cytoplasmic microinjection to confer disease resistance against porcine reproductive and respiratory syndrome [47]. Recently, gene editors have been utilized extensively for the rapid establishment of valuable engineered pig lines that can be used in human medicine, e.g., as disease models and organ donors.

\section{Disease models}

Pigs are among the best animals for disease models in medical research, which has implications for translational and preclinical research, as they are intermediate between mice and humans in terms of their physiological and anatomical relationships. Selection of the appropriate pig breed or strain, and age is important for the application of surgical and non-surgical procedures typically used in human medicine (e.g., catheterization, heart surgery, and endoscopy). These clinical procedures are particularly difficult or impossible to perform in many other animal models, including rodents, owing to the small size of the species. Various types of gene-edited pigs have been generated to establish models for intractable diseases (Table 1). Gene editing is expected to accelerate the application of pig lines as disease models.

\section{Tissuelorgan donors for pig-to-human transplantation}

Pigs are ideal tissue/organ donors for humans owing to the high similarity of their organs, especially in terms of size and structure. Pig-to-human xenotransplantation is a solution to the shortage of organs for human transplantation. However, xenoantigens cause hyperacute rejection and limit the success of interspecific xenografts. Therefore, genes involved in xenoantigen biosynthesis, such as GGTA1, CMAH, and B4GALNT2, are key targets for improving the 
Table 1. Gene-edited pigs to establish models for intractable diseases

\begin{tabular}{|c|c|c|c|c|c|}
\hline Disease & Gene targeted & Method & Editor & Reference & \\
\hline \multirow[t]{4}{*}{ Cancer } & DAZL, APC & $\mathrm{CT}$ & TALEN, CRISPR & Tan et al. (2013) & [125] \\
\hline & RUNX3 & SCNT & CRISPR & Kang et al. (2016) & [126] \\
\hline & ТР53 & SCNT & TALEN & Shen et al. (2017) & [127] \\
\hline & TP53 & EP & CRISPR & Tanihara et al. (2018) & [53] \\
\hline \multirow[t]{2}{*}{ Cardiomyopathy } & MYH7 & SCNT & TALEN & Montag et al. (2018) & {$[114]$} \\
\hline & SGCD & SCNT & TALEN & Matsunari et al. (2020) & [128] \\
\hline Cryopyrin-associated periodic syndrome & NLRP3 & SCNT & CRISPR & Li et al. (2020) & {$[116]$} \\
\hline \multirow[t]{3}{*}{ Diabetes } & INS & SCNT & CRISPR & Cho et al. (2018) & [129] \\
\hline & IAPP & SCNT & CRISPR & Zou et al. (2019) & [107] \\
\hline & PDX1 & $\mathrm{EP}$ & CRISPR & Tanihara et al. (2020) & [54] \\
\hline Duchenne muscular dystrophy & DMD & CMI & CRISPR & Yu et al. (2016) & [130] \\
\hline \multirow[t]{2}{*}{ Familial hypercholesterolemia } & LDLR & SCNT & TALEN & Carlson et al. (2012) & [59] \\
\hline & ApoE, LDLR & SCNT & CRISPR & Huang et al. (2017) & [131] \\
\hline \multirow[t]{2}{*}{ Human Waardenburg syndrome } & MITF & SCNT, CMI & CRISPR & Wang et al. (2015) & [132] \\
\hline & MITF & CMI & CRISPR & Hai et al. (2017) & [133] \\
\hline Hemophilia B & F9 & SCNT & CRISPR & Chen et al. (2020) & [134] \\
\hline Huntington's disease & HTT & SCNT & CRISPR & Yan et al. (2018) & [109] \\
\hline Hutchinson-Gilford progeria syndrome & NLRP3 & SCNT & CRISPR & Dorado et al. (2019) & [108] \\
\hline Leigh syndrome & SURF1 & SCNT & TALEN, CRISPR & Quadalti et al. (2018) & {$[135]$} \\
\hline Marfan syndrome & FBN1 & SCNT & ZFN & Umeyama et al. (2016) & [136] \\
\hline Ornithine transcarbamylase deficiency & OTC & SCNT & TALEN & Matsunari et al. (2018) & [137] \\
\hline \multirow[t]{4}{*}{ Parkinson's disease } & GGTA1, Parkin, DJ-1 & SCNT & TALEN & Yao et al. (2014) & {$[138]$} \\
\hline & TYR, PINK1, PARK2 & SCNT & CRISPR & Zhou et al. (2015) & [139] \\
\hline & Parkin, DJ-1, PINK1 & CMI & CRISPR & Wang et al. (2016) & [101] \\
\hline & SCNA & SCNT & CRISPR & Zhu et al. (2018) & [115] \\
\hline Phenylketonuria & PAH & CMI & CRISPR & Koppes et al. (2020) & [140] \\
\hline Polycystic kidney disease & PKD1 & SCNT & ZFN & He et al. (2015) & [141] \\
\hline von Willebrand disease & vWF & CMI & CRISPR & Hai et al. (2014) & {$[48]$} \\
\hline \multirow[t]{4}{*}{ X-linked severe combined immunodeficiency } & IL2RG & SCNT & ZFN & Watanabe et al. (2013) & [142] \\
\hline & IL2RG & SCNT, CMI & CRISPR & Kang et al. (2016) & [143] \\
\hline & IL2RG & CMI & CRISPR & Chen et al. (2019) & [144] \\
\hline & IL2RG & SCNT & CRISPR & Ren et al. (2020) & [145] \\
\hline
\end{tabular}

CT, chromatin transfer; SCNT, somatic cell nuclear transfer; CMI, cytoplasmic microinjection; EP, electroporation.

outcomes of xenotransplantation. GGTA1 is a major target gene, and its inactivation has been demonstrated using ZFNs [57, 60, 61], TALENs [62-64], and CRISPR/Cas9 [55, 65, 66]. However, for successful xenotransplantation, all major xenoantigens expressed in porcine tissues should be removed. To this end, GGTA1/CMAH double-knockout [37, 67-69] and GGTA1/CMAH/B4GALNT2 tripleknockout pigs $[39,70,71]$ have also been generated using SCNT and gene editing. Paris et al. demonstrated that organs derived from $A S G R 1$-deficient pigs exhibit decreased human platelet uptake, which may prevent xenotransplantation-induced thrombocytopenia [72]. Gene editors enable various approaches to regulating immune rejection.

Additional major hurdles for successful xenotransplantation are organ size and the elimination of porcine endogenous retrovirus (PERV). Xeno-organs donated by genetically modified pigs car- rying the genetic background of domestic pigs can grow rapidly; this can generate incompatibility with recipients and impair their long-term function after transplantation. Growth hormone receptor (GHR)-deficient pigs with reduced organ size [73, 74] and subsequent GHR/GGTA1 double-knockout pigs expressing the human cluster of differentiation ( $h C D 46)$ and human thrombomodulin ( $h T H B D)$ [75] have been generated by gene editing. This approach will improve the implementation of xenotransplantation. Furthermore, the risk of PERV transmission to humans after xenotransplantation is a concern $[76,77]$. PERVs constitute an integral part of the porcine genome and can be expressed as infectious virus particles. Infection by PERVs in human cells has been observed using in vitro co-culture assays, which demonstrated the possibility of a new epidemic infectious disease induced by xenotransplantation. PERVs are present in various proportions in the whole porcine genome, depending on the pig breed 
and tissue type, making the inactivation of PERVs a difficult task; however, genome-wide gene editing has the potential to eliminate PERVs from porcine tissues. Gene editing targeting PERVs has been demonstrated using CRISPR/Cas9 [78, 79], and PERV-inactivated pigs have also been generated using SCNT [80]. These hurdles have thus been partially overcome using various gene editing techniques in pigs, improving the feasibility of pig-to-human xenotransplantation.

An alternative strategy for producing functional and transplantable tissues or organs is to build interspecies chimeras at the embryonic level by blastocyst complementation, which involves the injection of human ESCs or human induced pluripotent stem cells into genetically modified porcine embryos lacking the ability to generate specific organs. Missing organs (empty niches) are expected to develop from these injected stem cells, resulting in the generation of organs derived from human cells. A proof-of-concept has been established via the generation of functional pancreases in mouse-rat interspecific chimeras [81]. Matsunari et al. demonstrated the compensation of disabled organogenesis by allogenic blastocyst complementation in pigs by injecting donor blastomeres into gene-edited host embryos [82]. However, at present, the utilization of stem cells for interspecies chimerism is quite limited with respect to pigs [83, 84]. Therefore, further investigations are required.

\section{Current Status and Future Prospects of Gene-edited Pigs}

Figure 2 summarizes recent trends in the number of articles reporting the generation of genetically modified pigs using gene editors available via PubMed. The search terms used were "pig," "ZFN," "TALEN," and "CRISPR"; these picked up studies demonstrating the production of gene-edited pigs/fetuses. The gene editors (ZFN, TALEN, and/or CRISPR-related systems) and methods for generating gene-edited pigs (SCNT, cytoplasmic microinjection, and/or electroporation) used in the studies were investigated. Although the introduction of gene editors during embryogenesis using microinjection or electroporation has an advantage over SCNT with respect to the simplicity of the procedure, the use of SCNT is more common. In this section, we discuss the limitations and future prospects of direct gene editing during embryogenesis.

\section{Mosaicism}

Genetic mosaicism, in which a single individual carries multiple genotypes, contributes to the inability to generate mutant pigs via direct gene editing during embryogenesis [85]. In founder animals, both the direct injection and electroporation-mediated introduction of gene editors into the cytoplasm often induce mosaicism due to the delayed expression of mRNA-related gene editors or remnant activity of the gene editors throughout the cell division process [85-89]. Mosaicism complicates the phenotypic analyses of founders, which require the F1 generation. Owing to the long gestation period and time to reach sexual maturity in pigs, production of the F1 generation involves a tremendous amount of time and cost, seriously limiting research progress. Mosaicism is detected by genotyping (e.g., by the detection of multiple alleles, typically three alleles or more, or extreme deviations in allele frequencies). We investigated previous examples of gene modification during embryogenesis by
A

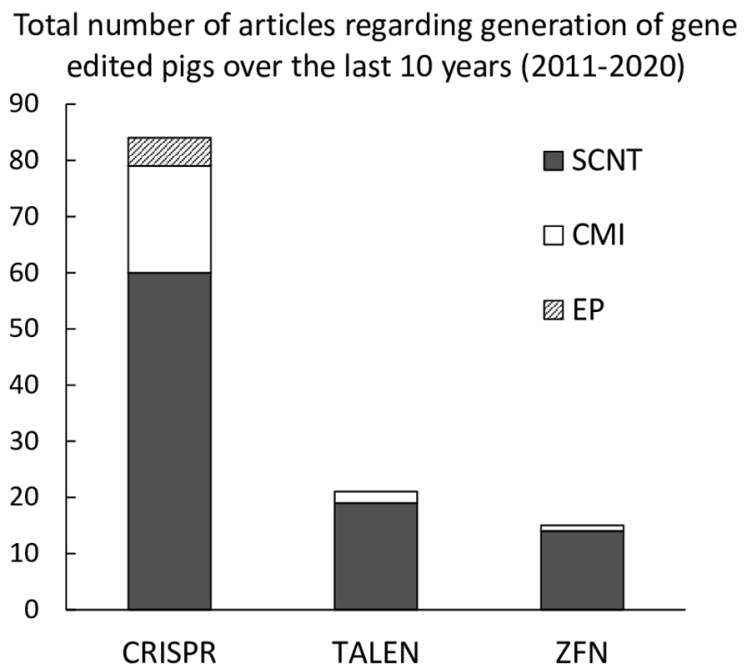

B

\section{Changes in the number of articles per year}

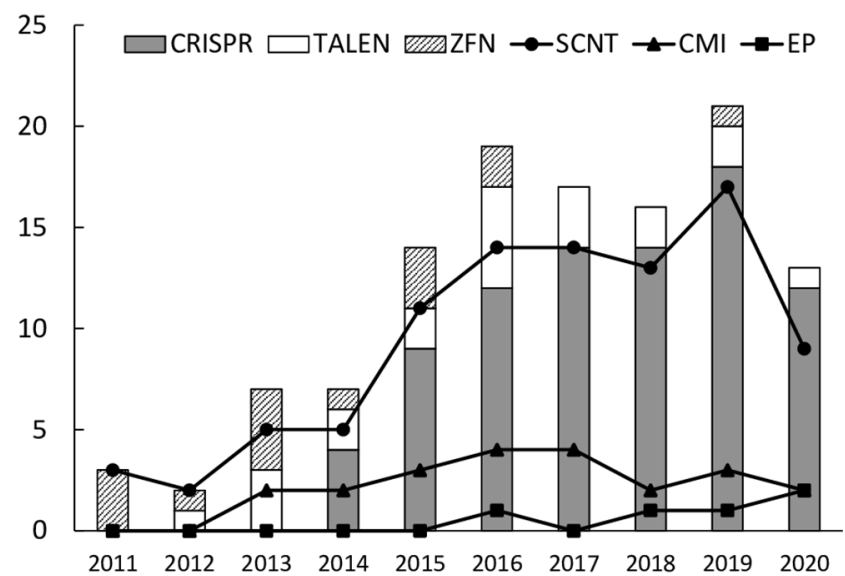

Fig. 2. Trends in recent reports on generating genetically modified pigs using gene editors. Number of PubMed articles reporting the generation of genetically modified pigs using gene editors over the last 10 years (2011-2020; search terms: "pig," "ZFN," "TALEN," and "CRISPR"). (A) Total number of articles. (B) Changes in the number of articles per year, including information on gene editors and the method used to generate mutant pigs. SCNT, somatic cell nuclear transfer; CMI, cytoplasmic microinjection into zygotes/embryos; EP, electroporation into zygotes/embryos; CRISPR, clustered regularly interspaced short palindromic repeats; Cas, CRISPR-associated protein; TALEN, transcription activator-like effector nuclease; ZFN, zinc finger nuclease. Studies using multiple gene editors or multiple methods used to generate mutant pigs were classified into each relevant category and were therefore double-counted. Studies using CRISPR/Cas-related methods (e.g., Cas9 nickase and FokI-dCas9) were classified under "CRISPR." 
Table 2. Gene editing efficiency and mosaicism of resulting offspring/fetuses in studies using cytoplasmic microinjection- or electroporationmediated gene editing

\begin{tabular}{|c|c|c|c|c|c|c|}
\hline \multicolumn{2}{|l|}{ Reference } & \multirow{3}{*}{$\begin{array}{c}\text { Method } \\
\text { CMI }\end{array}$} & \multirow[t]{2}{*}{ Gene targeted } & \multirow[t]{2}{*}{ Introduced components } & $\begin{array}{c}\text { Gene-edited/ } \\
\text { total offspring } \\
\text { and fetuses (\%) }\end{array}$ & $\begin{array}{c}\text { Mosaic/gene-edited } \\
(\%)\end{array}$ \\
\hline ZFN & & & & & & \\
\hline Lillico et al. (2013) & {$[46]$} & & RELA & mRNA & $1 / 9 \quad(11.1)$ & $0 / 1$ \\
\hline \multicolumn{7}{|l|}{ TALEN } \\
\hline Lillico et al. (2013) & {$[46]$} & CMI & RELA & mRNA & $8 / 39(20.5)$ & $(25.0)$ \\
\hline Wang et al. (2016) & [146] & CMI & $\mathrm{B} 2 \mathrm{M}$ & mRNA & $6 / 7 \quad(85.7)$ & $(50.0)$ \\
\hline \multicolumn{7}{|l|}{ CRISPR } \\
\hline Hai et al. (2014) & {$[48]$} & CMI & vWF & Cas9 mRNA and gRNA & $11 / 16(68.8)$ & 2 or more/11 \\
\hline \multirow[t]{2}{*}{ Whitworth et al. (2014) } & {$[47]$} & CMI & CD163 & Cas9 mRNA and gRNA & $4 / 4 \quad(100)$ & $0 / 4$ \\
\hline & & & CD1D & Cas9 mRNA and gRNA & $4 / 4 \quad(100)$ & $(25.0)$ \\
\hline Wang et al. (2015) & {$[132]$} & CMI & MITF & Cas9 mRNA and gRNA & $2 / 2 \quad(100)$ & $0 / 2$ \\
\hline Zhou et al. (2016) & {$[23]$} & CMI & Sox10 (point mutation) & Cas9 mRNA and gRNA & $12 / 12(100)$ & $8 / 12 \quad(66.7)$ \\
\hline Peng et al. (2015) & [49] & CMI & $\begin{array}{l}\text { recombinant human serum } \\
\text { albumin (knock-in) }\end{array}$ & Cas9 mRNA and gRNA & $16 / 16(100)$ & $1 / 16 \quad(6.25)$ \\
\hline Wang et al. (2016) & [101] & CMI & Parkin, DJ-1, PINK1 & Cas9 mRNA and gRNA & $2 / 2 \quad(100)$ & $0 / 2$ \\
\hline Petersen et al. (2016) & {$[66]$} & CMI & GGTA1 & Plasmid & $11 / 12(91.7)$ & $4 / 11 \quad(36.4)$ \\
\hline Yu et al. (2016) & {$[130]$} & CMI & DMD & Cas9 mRNA and gRNA & $1 / 2 \quad(50.0)$ & $(100)$ \\
\hline Kang et al. (2016) & [143] & CMI & IL2RG & Cas9 mRNA and gRNA & $4 / 6 \quad(66.7)$ & $0 / 4$ \\
\hline Park et al. (2017) & [147] & CMI & NANOS2 & Cas9 mRNA and gRNA & $18 / 18(100)$ & $5 / 18 \quad(27.8)$ \\
\hline Wu et al. (2017) & [148] & CMI & PDX1 & Cas9 mRNA and gRNA & $3 / 9 \quad(33.3)$ & $(66.7)$ \\
\hline Hai et al. (2017) & [133] & CMI & MITF & Cas9 mRNA and gRNA & $2 / 2 \quad(100)$ & $0 / 2$ \\
\hline Hinrichs et al. (2018) & {$[73]$} & CMI & GHR & Cas9 mRNA and gRNA & $3 / 8 \quad(37.5)$ & $0 / 3$ \\
\hline Xiang et al. (2018) & [149] & CMI & IGF2 & Nickase mRNA and gRNA & $6 / 6 \quad(100)$ & $(50.0)$ \\
\hline Whitworth et al. (2019) & {$[150]$} & CMI & ANPEP & Cas9 mRNA and gRNA & $13 / 18(72.2)$ & $3 / 13 \quad(23.1)$ \\
\hline Tu et al. (2019) & [151] & CMI & $\begin{array}{l}\text { CMP-N-glycolylneuraminic } \\
\text { acid hydroxylase }\end{array}$ & Cas9 mRNA and gRNA & $5 / 6 \quad(83.3)$ & $(60.0)$ \\
\hline Chen et al. (2019) & [144] & CMI & TYR, IL2RG, RAG1 & Cas 9 mRNA and gRNA & 15/16 (93.8) & $5 / 15 \quad(33.3)$ \\
\hline Tanihara et al. (2016) & {$[52]$} & $\mathrm{EP}$ & MSTN & Cas9 protein and gRNA & $9 / 10(90.0)$ & $(44.4)$ \\
\hline Tanihara et al. (2018) & {$[53]$} & EP & TP53 & Cas9 protein and gRNA & $6 / 9 \quad(66.7)$ & $(66.7)$ \\
\hline Tanihara et al. (2020) & {$[54]$} & EP & PDX & Cas9 protein and gRNA & 9/10 (90.0) & (44.4) \\
\hline Tanihara et al. (2020) & {$[55]$} & EP & GGTA1 & Cas 9 protein and gRNA & $5 / 6 \quad(83.3)$ & $(40.0)$ \\
\hline
\end{tabular}

CMI, cytoplasmic microinjection; EP, electroporation. In this table, offspring/fetuses carrying three alleles or more, or extreme deviations in allele frequencies are denoted as mosaic.

cytoplasmic microinjection or electroporation using gene editors, including TALENs and ZFNs, and found that mosaicism in gene-edited offspring was reported in 18 out of 23 studies (Table 2). Mosaicism occurs at various frequencies [85], and the type of gene editor and modification [90, 91], introduction method, animal species, and introduced component of gene editors (e.g., expression plasmid, mRNA, and protein/nuclease) seem to be potential factors.

Appropriate timing of the introduction of gene editors during embryogenesis is considered a key factor in reducing mosaicism [87]. Microinjection of the CRISPR/Cas9 system into the cytoplasm of germinal vesicle-stage oocytes successfully generated non-mosaic genome-edited porcine embryos [92]. Onuma et al. demonstrated that microinjection of the CRISPR/Cas9 system during meiotic maturation preferentially induces heterozygous mutations without mosaicism after germinal vesicle breakdown and chromosome condensation [93]. Conversely, electroporation-mediated gene editing in mature oocytes has demonstrated that the type of egg may influence development after electroporation treatment and the mutation rate in the resulting blastocyst; however, mosaicism is not controlled [94]. A simple approach, the optimization of CRISPR/Cas9 component concentrations, is effective in increasing gene editing efficiency in cytoplasmic microinjection [95] and electroporation [96]. Such strategies will improve gene editing efficiency during embryogenesis. Further optimization of the methods for the application of gene editors in pigs is required.

\section{Multiple gene editing}

Currently, the generation of multiple-gene-edited pigs is an important research goal aimed at a better understanding of complex biological processes and the management of redundancies and 
compensatory changes in signaling pathways. Gene editors can induce mutations in multiple targeting sites, enabling the one-step generation of double- and triple-knockout pigs via direct introduction into zygotes/embryos. Multiple-gene-edited animals have been generated by cytoplasmic microinjection of CRISPR/Cas9 in mice [97, 98], rats [99], and monkeys [100]. In pigs, the SCNT technique is the primary method, as described above, and there are few reports of one-step generation of multiple-gene-edited pigs by microinjection or electroporation [101]. As the number of simultaneously targeted genes increases, the risk of insufficient gene knockout, including mosaicism, will also increase. The investigation of in vitro electroporation-mediated multiple-gene editing has progressed $[102,103]$. The reductions in mosaicism and the optimization of multiple-gene editing efficiency in zygotes/embryos achieved to date are inadequate; highly efficient direct gene modification is expected to be achieved in the near future.

\section{Knock-in during embryogenesis}

Knock-in of transgene(s) is a crucial approach for the generation of valuable pigs for experimental research, such as those with knock-in of human complement regulatory proteins (CD46, CD55, CD59, etc.) to reduce complement activity in xenotransplantation [41]. Although most knock-in pigs have been generated by SCNT using gene-edited somatic cells carrying transgenes as donor cells [31, 43, 44, 104-109], cytoplasmic microinjection of gene editors can also be used to successfully generate knock-in pigs [49, 110]. However, knock-in pigs have not been successfully generated by electroporation-mediated methods, because the introduction of large transgenes for knock-in is difficult using electroporation alone in pigs, as described above. Direct knock-in during embryogenesis using gene editors has a wide range of applications. Although HDR followed by DSBs induced by a gene editor facilitates the generation of knock-in animals, the HDR efficiency and the resulting rate of knock-in events are low [16], in contrast to the high efficiency of Cas9 cleavage. Accordingly, the system needs to be optimized for practical use.

Various issues need to be resolved to achieve electroporationmediated knock-in of transgenes into zygotes/embryos. Owing to the greater sensitivity of in vitro-fertilized porcine zygotes to electricity compared with that of in vivo-derived mouse embryos $[52,56]$, the size of molecules that can be introduced into zygotes/ embryos is limited. To efficiently deliver knock-in donor DNA into zygotes without mechanical injury, an adeno-associated viral (AAV) vector has been applied in mice [111] and rats [112] without removing the zona pellucida. Although AAV vector-mediated gene modification in porcine cells has been adapted to generate mutant pigs by combining it with SCNT techniques [113], the investigation of gene modification during embryogenesis via an AAV vector is insufficient. The development of new and efficient techniques for delivering large molecules into zygotes and embryos is crucial.

\section{Introduction of point mutations during embryogenesis}

A large number of disease-causing single-nucleotide polymorphisms have been identified in humans. Although post-DSB gene corrections by gene editors often induce random insertions and deletions at the target locus, the co-introduction of an ssODN as a template enables the introduction of point mutations in precise positions via the HDR pathway. In the use of gene editors, challenges related to the establishment of human disease models originating from point mutations [23, 114-116] and humanized pigs expressing human insulin [117] have been reported. However, the SCNT technique was used in almost all of these studies [114-117]. Inhibition of NHEJ or enhancement of HDR is crucial for achieving targeted gene knock-ins or point mutations at precise positions during embryogenesis [118]. At present, the low frequency of HDRs in porcine zygotes/embryos limits the utilization of this methodology. Despite progress in trials aimed at enhancing HDR using an NHEJ inhibitor or HDR enhancer in cell lines and mouse/rabbit embryos [119], studies using porcine zygotes/embryos are required.

The CRISPR/Cas-mediated base editor system, another approach for the introduction of a point mutation at a precise position without dependence on HDR, generates mutations at a single-base level [120, 121]. Cytosine base editors convert targeted $\mathrm{C}-\mathrm{G}$ base pairs to $\mathrm{T}-\mathrm{A}$ pairs, and adenine base editors convert targeted A-T pairs into $\mathrm{G}-\mathrm{C}$ pairs without causing DSBs. Wang et al. demonstrated base editing in porcine fetal fibroblast cells using a modified base editor system [122], and Xie et al. generated base-edited pigs via cytoplasmic microinjection and SCNT [123]. These studies further support the feasibility of using pigs as human disease models. Although there are some technical limitations, such as insufficient specificity, protospacer adjacent motif (PAM) compatibility concerns, and a narrow active window [124], this technology has the potential to revolutionize gene therapy for genetic diseases and enable the efficient generation of animal models of diseases.

\section{Conclusion}

Owing to the development of gene-editing technologies, the generation of genetically modified pigs has dramatically expanded. However, some limitations remain. SCNT using gene-edited somatic cells ensures the generation of desired mutations in the resulting pigs, but requires sophisticated techniques. Microinjection- and electroporation-mediated gene editing are simple but limited by insecure knockout/knock-in efficiencies and mosaicism. However, various types of gene editors and their related technologies can be effectively applied to pigs using optimized and appropriate methods for introduction. In the future, gene editors will enable the on-demand preparation of pigs carrying desired mutations, including precise knock-ins.

Conflicts of interests: The authors declare no conflicts of interest.

\section{References}

1. Bähr A, Wolf E. Domestic animal models for biomedical research. Reprod Domest Anim 2012; 47(Suppl 4): 59-71. [Medline] [CrossRef]

2. Hammer RE, Pursel VG, Rexroad CE Jr, Wall RJ, Bolt DJ, Ebert KM, Palmiter RD, Brinster RL. Production of transgenic rabbits, sheep and pigs by microinjection. Nature 1985; 315: 680-683. [Medline] [CrossRef]

3. Uchida M, Shimatsu Y, Onoe K, Matsuyama N, Niki R, Ikeda JE, Imai H. Production of transgenic miniature pigs by pronuclear microinjection. Transgenic Res 2001; 10: 577-582. [Medline] [CrossRef]

4. Nagashima H, Fujimura T, Takahagi Y, Kurome M, Wako N, Ochiai T, Esaki R, Kano K, Saito S, Okabe M, Murakami H. Development of efficient strategies for the 
production of genetically modified pigs. Theriogenology 2003; 59: 95-106. [Medline] [CrossRef]

5. Shiue YL, Yang JR, Liao YJ, Kuo TY, Liao CH, Kang CH, Tai C, Anderson GB, Chen LR. Derivation of porcine pluripotent stem cells for biomedical research. Theriogenology 2016; 86: 176-181. [Medline] [CrossRef]

6. Polejaeva IA, Chen SH, Vaught TD, Page RL, Mullins J, Ball S, Dai Y, Boone J, Walker S, Ayares DL, Colman A, Campbell KH. Cloned pigs produced by nuclear transfer from adult somatic cells. Nature 2000; 407: 86-90. [Medline] [CrossRef]

7. Onishi A, Iwamoto M, Akita T, Mikawa S, Takeda K, Awata T, Hanada H, Perry AC. Pig cloning by microinjection of fetal fibroblast nuclei. Science 2000; 289: 1188-1190. [Medline] [CrossRef]

8. Betthauser J, Forsberg E, Augenstein M, Childs L, Eilertsen K, Enos J, Forsythe T, Golueke P, Jurgella G, Koppang R, Lesmeister T, Mallon K, Mell G, Misica P, Pace M, Pfister-Genskow M, Strelchenko N, Voelker G, Watt S, Thompson S, Bishop M. Production of cloned pigs from in vitro systems. Nat Biotechnol 2000; 18: 1055-1059. [Medline] [CrossRef]

9. Niemann H, Lucas-Hahn A. Somatic cell nuclear transfer cloning: practical applications and current legislation. Reprod Domest Anim 2012; 47(Suppl 5): 2-10. [Medline] [CrossRef]

10. Kim YG, Cha J, Chandrasegaran S. Hybrid restriction enzymes: zinc finger fusions to Fok I cleavage domain. Proc Natl Acad Sci USA 1996; 93: 1156-1160. [Medline] [CrossRef]

11. Miller JC, Holmes MC, Wang J, Guschin DY, Lee YL, Rupniewski I, Beausejour CM, Waite AJ, Wang NS, Kim KA, Gregory PD, Pabo CO, Rebar EJ. An improved zinc-finger nuclease architecture for highly specific genome editing. Nat Biotechnol 2007; 25: 778-785. [Medline] [CrossRef]

12. Christian M, Cermak T, Doyle EL, Schmidt C, Zhang F, Hummel A, Bogdanove AJ, Voytas DF. Targeting DNA double-strand breaks with TAL effector nucleases. Genetics 2010; 186: 757-761. [Medline] [CrossRef]

13. Cong L, Ran FA, Cox D, Lin S, Barretto R, Habib N, Hsu PD, Wu X, Jiang W, Marraffini LA, Zhang F. Multiplex genome engineering using CRISPR/Cas systems. Science 2013; 339: 819-823. [Medline] [CrossRef]

14. Mali P, Yang L, Esvelt KM, Aach J, Guell M, DiCarlo JE, Norville JE, Church GM. RNA-guided human genome engineering via Cas9. Science 2013; 339: 823-826. [Medline] [CrossRef]

15. Kanaar R, Hoeijmakers JH, van Gent DC. Molecular mechanisms of DNA double strand break repair. Trends Cell Biol 1998; 8: 483-489. [Medline] [CrossRef]

16. Sonoda E, Hochegger H, Saberi A, Taniguchi Y, Takeda S. Differential usage of nonhomologous end-joining and homologous recombination in double strand break repair. DNA Repair (Amst) 2006; 5: 1021-1029. [Medline] [CrossRef]

17. Maeder ML, Thibodeau-Beganny S, Sander JD, Voytas DF, Joung JK. Oligomerized pool engineering (OPEN): an 'open-source' protocol for making customized zinc-finger arrays. Nat Protoc 2009; 4: 1471-1501. [Medline] [CrossRef]

18. Jinek M, Chylinski K, Fonfara I, Hauer M, Doudna JA, Charpentier E. A programmable dual-RNA-guided DNA endonuclease in adaptive bacterial immunity. Science 2012; 337: 816-821. [Medline] [CrossRef]

19. Manghwar H, Li B, Ding X, Hussain A, Lindsey K, Zhang X, Jin S. CRISPR/Cas systems in genome editing: methodologies and tools for sgRNA design, off-target evaluation, and strategies to mitigate off-target effects. Adv Sci (Weinh) 2020; 7: 1902312. [Medline] [CrossRef]

20. Fu Y, Foden JA, Khayter C, Maeder ML, Reyon D, Joung JK, Sander JD. Highfrequency off-target mutagenesis induced by CRISPR-Cas nucleases in human cells. Nat Biotechnol 2013; 31: 822-826. [Medline] [CrossRef]

21. Chandrasegaran S, Carroll D. Origins of programmable nucleases for genome engineering. J Mol Biol 2016; 428(5 Pt B): 963-989. [Medline] [CrossRef]

22. Carey K, Ryu J, Uh K, Lengi AJ, Clark-Deener S, Corl BA, Lee K. Frequency of off-targeting in genome edited pigs produced via direct injection of the CRISPR/Cas9 system into developing embryos. BMC Biotechnol 2019; 19: 25. [Medline] [CrossRef]

23. Zhou X, Wang L, Du Y, Xie F, Li L, Liu Y, Liu C, Wang S, Zhang S, Huang X, Wang Y, Wei H. Efficient generation of gene-modified pigs harboring precise orthologous human mutation via CRISPR/Cas9-induced homology-directed repair in zygotes. Hum Mutat 2016; 37: 110-118. [Medline] [CrossRef]

24. Yang D, Yang H, Li W, Zhao B, Ouyang Z, Liu Z, Zhao Y, Fan N, Song J, Tian J, Li F, Zhang J, Chang L, Pei D, Chen YE, Lai L. Generation of PPAR $\gamma$ mono-allelic knockout pigs via zinc-finger nucleases and nuclear transfer cloning. Cell Res 2011; 21: 979-982. [Medline] [CrossRef]

25. Wang K, Ouyang H, Xie Z, Yao C, Guo N, Li M, Jiao H, Pang D. Efficient generation of myostatin mutations in pigs using the CRISPR/Cas9 system. Sci Rep 2015; 5: 16623. [Medline] [CrossRef]

26. Zhang W, Wang G, Wang Y, Jin Y, Zhao L, Xiong Q, Zhang L, Mou L, Li R, Yang H, Dai Y. Generation of complement protein C3 deficient pigs by CRISPR/Cas9-mediated gene targeting. Sci Rep 2017; 7: 5009. [Medline] [CrossRef]
27. Choi K, Shim J, Ko N, Park J. No excessive mutations in transcription activator-like effector nuclease-mediated $\alpha$-1,3-galactosyltransferase knockout Yucatan miniature pigs. Asian-Australas J Anim Sci 2020; 33: 360-372. [Medline] [CrossRef]

28. Naeem M, Majeed S, Hoque MZ, Ahmad I. Latest developed strategies to minimize the off-target effects in CRISPR-Cas-mediated genome editing. Cells 2020; 9: 9. [Medline] [CrossRef]

29. Ran FA, Hsu PD, Lin CY, Gootenberg JS, Konermann S, Trevino AE, Scott DA, Inoue A, Matoba S, Zhang Y, Zhang F. Double nicking by RNA-guided CRISPR Cas9 for enhanced genome editing specificity. Cell 2013; 154: 1380-1389. [Medline] [CrossRef]

30. Saifaldeen M, Al-Ansari DE, Ramotar D, Aouida M. CRISPR FokI dead Cas9 system principles and applications in genome engineering. Cells 2020; 9: 9. [Medline] [CrossRef]

31. Nottle MB, Salvaris EJ, Fisicaro N, McIlfatrick S, Vassiliev I, Hawthorne WJ, O'Connell PJ, Brady JL, Lew AM, Cowan PJ. Targeted insertion of an anti-CD2 monoclonal antibody transgene into the GGTA1 locus in pigs using FokI-dCas9. Sci Rep 2017; 7: 8383. [Medline] [CrossRef]

32. Kleinstiver BP, Pattanayak V, Prew MS, Tsai SQ, Nguyen NT, Zheng Z, Joung JK. High-fidelity CRISPR-Cas9 nucleases with no detectable genome-wide off-target effects. Nature 2016; 529: 490-495. [Medline] [CrossRef]

33. Casini A, Olivieri M, Petris G, Montagna C, Reginato G, Maule G, Lorenzin F, Prandi D, Romanel A, Demichelis F, Inga A, Cereseto A. A highly specific SpCas9 variant is identified by in vivo screening in yeast. Nat Biotechnol 2018; 36: 265-271. [Medline] [CrossRef]

34. Slaymaker IM, Gao L, Zetsche B, Scott DA, Yan WX, Zhang F. Rationally engineered Cas9 nucleases with improved specificity. Science 2016; 351: 84-88. [Medline] [CrossRef]

35. Chen JS, Dagdas YS, Kleinstiver BP, Welch MM, Sousa AA, Harrington LB, Sternberg SH, Joung JK, Yildiz A, Doudna JA. Enhanced proofreading governs CRISPRCas9 targeting accuracy. Nature 2017; 550: 407-410. [Medline] [CrossRef]

36. Huang J, Guo X, Fan N, Song J, Zhao B, Ouyang Z, Liu Z, Zhao Y, Yan Q, Yi X, Schambach A, Frampton J, Esteban MA, Yang D, Yang H, Lai L. RAG1/2 knockout pigs with severe combined immunodeficiency. J Immunol 2014; 193: 1496-1503. [Medline] [CrossRef]

37. Butler JR, Wang ZY, Martens GR, Ladowski JM, Li P, Tector M, Tector AJ. Modified glycan models of pig-to-human xenotransplantation do not enhance the human-antipig T cell response. Transpl Immunol 2016; 35: 47-51. [Medline] [CrossRef]

38. Xu K, Zhou Y, Mu Y, Liu Z, Hou S, Xiong Y, Fang L, Ge C, Wei Y, Zhang X, Xu C, Che J, Fan Z, Xiang G, Guo J, Shang H, Li H, Xiao S, Li J, Li K. CD163 and $p A P N$ double-knockout pigs are resistant to PRRSV and TGEV and exhibit decreased susceptibility to PDCoV while maintaining normal production performance. eLife 2020; 9: 9. [Medline] [CrossRef]

39. Estrada JL, Martens G, Li P, Adams A, Newell KA, Ford ML, Butler JR, Sidner R, Tector M, Tector J. Evaluation of human and non-human primate antibody binding to pig cells lacking GGTA1/CMAH/ß4GalNT2 genes. Xenotransplantation 2015; 22: 194-202. [Medline] [CrossRef]

40. Li P, Estrada JL, Burlak C, Montgomery J, Butler JR, Santos RM, Wang ZY, Paris LL, Blankenship RL, Downey SM, Tector M, Tector AJ. Efficient generation of genetically distinct pigs in a single pregnancy using multiplexed single-guide RNA and carbohydrate selection. Xenotransplantation 2015; 22: 20-31. [Medline] [CrossRef]

41. Lee W, Hara H, Ezzelarab MB, Iwase H, Bottino R, Long C, Ramsoondar J, Ayares D, Cooper DK. Initial in vitro studies on tissues and cells from $\mathrm{GTKO} / \mathrm{CD} 46 / \mathrm{NeuGcKO}$ pigs. Xenotransplantation 2016; 23: 137-150. [Medline] [CrossRef]

42. Kim GA, Lee EM, Jin JX, Lee S, Taweechaipaisankul A, Hwang JI, Alam Z, Ahn C, Lee BC. Generation of CMAHKO/GTKO/shTNFRI-Fc/HO-1 quadruple gene modified pigs. Transgenic Res 2017; 26: 435-445. [Medline] [CrossRef]

43. Ruan J, Li H, Xu K, Wu T, Wei J, Zhou R, Liu Z, Mu Y, Yang S, Ouyang H, ChenTsai RY, Li K. Highly efficient CRISPR/Cas9-mediated transgene knockin at the H11 locus in pigs. Sci Rep 2015; 5: 14253. [Medline] [CrossRef]

44. Lai S, Wei S, Zhao B, Ouyang Z, Zhang Q, Fan N, Liu Z, Zhao Y, Yan Q, Zhou X Li L, Xin J, Zeng Y, Lai L, Zou Q. Generation of knock-in pigs carrying Oct4-tdTomato reporter through CRISPR/Cas9-mediated genome engineering. PLoS One 2016; 11: e0146562. [Medline] [CrossRef]

45. Kurome M, Geistlinger L, Kessler B, Zakhartchenko V, Klymiuk N, Wuensch A, Richter A, Baehr A, Kraehe K, Burkhardt K, Flisikowski K, Flisikowska T, Merkl C, Landmann M, Durkovic M, Tschukes A, Kraner S, Schindelhauer D, Petri T, Kind A, Nagashima H, Schnieke A, Zimmer R, Wolf E. Factors influencing the efficiency of generating genetically engineered pigs by nuclear transfer: multi-factorial analysis of a large data set. BMC Biotechnol 2013; 13: 43. [Medline] [CrossRef]

46. Lillico SG, Proudfoot C, Carlson DF, Stverakova D, Neil C, Blain C, King TJ, Ritchie WA, Tan W, Mileham AJ, McLaren DG, Fahrenkrug SC, Whitelaw CB. Live pigs produced from genome edited zygotes. Sci Rep 2013; 3: 2847. [Medline] [CrossRef]

47. Whitworth KM, Lee K, Benne JA, Beaton BP, Spate LD, Murphy SL, Samuel MS, 
Mao J, O'Gorman C, Walters EM, Murphy CN, Driver J, Mileham A, McLaren D, Wells KD, Prather RS. Use of the CRISPR/Cas9 system to produce genetically engineered pigs from in vitro-derived oocytes and embryos. Biol Reprod 2014; 91: 78. [Medline] [CrossRef]

48. Hai T, Teng F, Guo R, Li W, Zhou Q. One-step generation of knockout pigs by zygote injection of CRISPR/Cas system. Cell Res 2014; 24: 372-375. [Medline] [CrossRef]

49. Peng J, Wang Y, Jiang J, Zhou X, Song L, Wang L, Ding C, Qin J, Liu L, Wang W, Liu J, Huang X, Wei H, Zhang P. Production of human albumin in pigs through CRISPR/Cas9-mediated knockin of human cDNA into swine albumin locus in the zygotes. Sci Rep 2015; 5: 16705. [Medline] [CrossRef]

50. Tan W, Proudfoot C, Lillico SG, Whitelaw CB. Gene targeting, genome editing: from Dolly to editors. Transgenic Res 2016; 25: 273-287. [Medline] [CrossRef]

51. Sato M, Takabayashi S, Akasaka E, Nakamura S. Recent advances and future perspectives of in vivo targeted delivery of genome-editing reagents to germ cells, embryos, and fetuses in mice. Cells 2020; 9: 9. [Medline] [CrossRef]

52. Tanihara F, Takemoto T, Kitagawa E, Rao S, Do LT, Onishi A, Yamashita Y, Kosugi C, Suzuki H, Sembon S, Suzuki S, Nakai M, Hashimoto M, Yasue A, Matsuhisa M, Noji S, Fujimura T, Fuchimoto D, Otoi T. Somatic cell reprogramming-free generation of genetically modified pigs. Sci Adv 2016; 2: e1600803. [Medline] [CrossRef]

53. Tanihara F, Hirata M, Nguyen NT, Le QA, Hirano T, Takemoto T, Nakai M, Fuchimoto DI, Otoi T. Generation of a TP53-modified porcine cancer model by CRISPR/ Cas9-mediated gene modification in porcine zygotes via electroporation. PLoS One 2018; 13: e0206360. [Medline] [CrossRef]

54. Tanihara F, Hirata M, Thi Nguyen N, Anh Le Q, Hirano T, Otoi T. Generation of viable PDX1 gene-edited founder pigs as providers of nonmosaics. Mol Reprod Dev 2020; 87: 471-481. [Medline] [CrossRef]

55. Tanihara F, Hirata M, Nguyen NT, Sawamoto O, Kikuchi T, Doi M, Otoi T. Efficient generation of GGTA1-deficient pigs by electroporation of the CRISPR/Cas9 system into in vitro-fertilized zygotes. BMC Biotechnol 2020; 20: 40. [Medline] [CrossRef]

56. Nishio K, Tanihara F, Nguyen TV, Kunihara T, Nii M, Hirata M, Takemoto T, Otoi T. Effects of voltage strength during electroporation on the development and quality of in vitro-produced porcine embryos. Reprod Domest Anim 2018; 53: 313-318. [Medline] [CrossRef]

57. Hauschild J, Petersen B, Santiago Y, Queisser AL, Carnwath JW, Lucas-Hahn A, Zhang L, Meng X, Gregory PD, Schwinzer R, Cost GJ, Niemann H. Efficient generation of a biallelic knockout in pigs using zinc-finger nucleases. Proc Natl Acad Sci USA 2011; 108: 12013-12017. [Medline] [CrossRef]

58. Whyte JJ, Zhao J, Wells KD, Samuel MS, Whitworth KM, Walters EM, Laughlin MH, Prather RS. Gene targeting with zinc finger nucleases to produce cloned eGFP knockout pigs. Mol Reprod Dev 2011; 78: 2. [Medline] [CrossRef]

59. Carlson DF, Tan W, Lillico SG, Stverakova D, Proudfoot C, Christian M, Voytas DF, Long CR, Whitelaw CB, Fahrenkrug SC. Efficient TALEN-mediated gene knockout in livestock. Proc Natl Acad Sci USA 2012; 109: 17382-17387. [Medline] [CrossRef]

60. Li P, Estrada JL, Burlak C, Tector AJ. Biallelic knockout of the $\alpha-1,3$ galactosyltransferase gene in porcine liver-derived cells using zinc finger nucleases. J Surg Res 2013; 181: e39-e45. [Medline] [CrossRef]

61. Bao L, Chen H, Jong U, Rim C, Li W, Lin X, Zhang D, Luo Q, Cui C, Huang H, Zhang Y, Xiao L, Fu Z. Generation of GGTA1 biallelic knockout pigs via zinc-finger nucleases and somatic cell nuclear transfer. Sci China Life Sci 2014; 57: 263-268. [Medline] [CrossRef]

62. Xin J, Yang H, Fan N, Zhao B, Ouyang Z, Liu Z, Zhao Y, Li X, Song J, Yang Y, Zou Q, Yan Q, Zeng Y, Lai L. Highly efficient generation of GGTA1 biallelic knockout inbred mini-pigs with TALENs. PLoS One 2013; 8: e84250. [Medline] [CrossRef]

63. Kang JT, Kwon DK, Park AR, Lee EJ, Yun YJ, Ji DY, Lee K, Park KW. Production of $\alpha 1,3$-galactosyltransferase targeted pigs using transcription activator-like effector nuclease-mediated genome editing technology. J Vet Sci 2016; 17: 89-96. [Medline] [CrossRef]

64. Cheng W, Zhao H, Yu H, Xin J, Wang J, Zeng L, Yuan Z, Qing Y, Li H, Jia B, Yang C, Shen Y, Zhao L, Pan W, Zhao HY, Wang W, Wei HJ. Efficient generation of GGTA1-null Diannan miniature pigs using TALENs combined with somatic cell nuclear transfer. Reprod Biol Endocrinol 2016; 14: 77. [Medline] [CrossRef]

65. Chuang CK, Chen CH, Huang CL, Su YH, Peng SH, Lin TY, Tai HC, Yang TS, Tu CF. Generation of GGTA1 mutant pigs by direct pronuclear microinjection of CRISPR/ Cas9 plasmid vectors. Anim Biotechnol 2017; 28: 174-181. [Medline] [CrossRef]

66. Petersen B, Frenzel A, Lucas-Hahn A, Herrmann D, Hassel P, Klein S, Ziegler M, Hadeler KG, Niemann H. Efficient production of biallelic GGTA1 knockout pigs by cytoplasmic microinjection of CRISPR/Cas9 into zygotes. Xenotransplantation 2016; 23: 338-346. [Medline] [CrossRef]

67. Miyagawa S, Matsunari H, Watanabe M, Nakano K, Umeyama K, Sakai R, Takayanagi S, Takeishi T, Fukuda T, Yashima S, Maeda A, Eguchi H, Okuyama H, Nagaya M, Nagashima H. Generation of $\alpha 1,3$-galactosyltransferase and cytidine monophospho$\mathrm{N}$-acetylneuraminic acid hydroxylase gene double-knockout pigs. J Reprod Dev 2015; 61 :
449-457. [Medline] [CrossRef]

68. Fischer K, Kraner-Scheiber S, Petersen B, Rieblinger B, Buermann A, Flisikowska T, Flisikowski K, Christan S, Edlinger M, Baars W, Kurome M, Zakhartchenko V, Kessler B, Plotzki E, Szczerbal I, Switonski M, Denner J, Wolf E, Schwinzer R, Niemann H, Kind A, Schnieke A. Efficient production of multi-modified pigs for xenotransplantation by 'combineering', gene stacking and gene editing. Sci Rep 2016; 6 : 29081. [Medline] [CrossRef]

69. Gao H, Zhao C, Xiang X, Li Y, Zhao Y, Li Z, Pan D, Dai Y, Hara H, Cooper DK, Cai Z, Mou L. Production of $\alpha 1,3$-galactosyltransferase and cytidine monophosphate$\mathrm{N}$-acetylneuraminic acid hydroxylase gene double-deficient pigs by CRISPR/Cas9 and handmade cloning. J Reprod Dev 2017; 63: 17-26. [Medline] [CrossRef]

70. Zhang R, Wang Y, Chen L, Wang R, Li C, Li X, Fang B, Ren X, Ruan M, Liu J, Xiong Q, Zhang L, Jin Y, Zhang M, Liu X, Li L, Chen Q, Pan D, Li R, Cooper DKC, Yang H, Dai Y. Reducing immunoreactivity of porcine bioprosthetic heart valves genetically-deleting three major glycan antigens, GGTA1/34GalNT2/CMAH. Acta Biomater 2018; 72: 196-205. [Medline] [CrossRef]

71. Fischer K, Rieblinger B, Hein R, Sfriso R, Zuber J, Fischer A, Klinger B, Liang W, Flisikowski K, Kurome M, Zakhartchenko V, Kessler B, Wolf E, Rieben R, Schwinzer R, Kind A, Schnieke A. Viable pigs after simultaneous inactivation of porcine MHC class I and three xenoreactive antigen genes GGTA1, CMAH and B4GALNT2. Xenotransplantation 2020; 27: e12560. [Medline] [CrossRef]

72. Paris LL, Estrada JL, Li P, Blankenship RL, Sidner RA, Reyes LM, Montgomery JB, Burlak C, Butler JR, Downey SM, Wang ZY, Tector M, Tector AJ. Reduced human platelet uptake by pig livers deficient in the asialoglycoprotein receptor 1 protein. Xenotransplantation 2015; 22: 203-210. [Medline] [CrossRef]

73. Hinrichs A, Kessler B, Kurome M, Blutke A, Kemter E, Bernau M, Scholz AM, Rathkolb B, Renner S, Bultmann S, Leonhardt H, de Angelis MH, Nagashima H, Hoeflich A, Blum WF, Bidlingmaier M, Wanke R, Dahlhoff M, Wolf E. Growth hormone receptor-deficient pigs resemble the pathophysiology of human Laron syndrome and reveal altered activation of signaling cascades in the liver. Mol Metab 2018; 11: 113-128. [Medline] [CrossRef]

74. Yu H, Long W, Zhang X, Xu K, Guo J, Zhao H, Li H, Qing Y, Pan W, Jia B, Zhao HY, Huang X, Wei HJ. Generation of GHR-modified pigs as Laron syndrome models via a dual-sgRNAs/Cas9 system and somatic cell nuclear transfer. $J$ Transl Med 2018; 16: 41 Medline] [CrossRef]

75. Hinrichs A, Riedel EO, Klymiuk N, Blutke A, Kemter E, Längin M, Dahlhoff M, Keßler B, Kurome M, Zakhartchenko V, Jemiller EM, Ayares D, Bidlingmaier M, Flenkenthaler F, Hrabě de Angelis M, Arnold GJ, Reichart B, Fröhlich T, Wolf E. Growth hormone receptor knockout to reduce the size of donor pigs for preclinical xenotransplantation studies. Xenotransplantation 2020; 28: e12664. [Medline]

76. Lopata K, Wojdas E, Nowak R, Lopata P, Mazurek U. Porcine endogenous retrovirus (PERV) - molecular structure and replication strategy in the context of retroviral infection risk of human cells. Front Microbiol 2018; 9: 730. [Medline] [CrossRef]

77. Denner J, Tönjes RR. Infection barriers to successful xenotransplantation focusing on porcine endogenous retroviruses. Clin Microbiol Rev 2012; 25: 318-343. [Medline] [CrossRef]

78. Yang L, Güell M, Niu D, George H, Lesha E, Grishin D, Aach J, Shrock E, Xu W, Poci J, Cortazio R, Wilkinson RA, Fishman JA, Church G. Genome-wide inactivation of porcine endogenous retroviruses (PERVs). Science 2015; 350: 1101-1104. [Medline] [CrossRef]

79. Hirata M, Wittayarat M, Hirano T, Nguyen NT, Le QA, Namula Z, Fahrudin M, Tanihara F, Otoi T. The relationship between embryonic development and the efficiency of target mutations in porcine endogenous retroviruses (PERVs) Pol genes in porcine embryos. Animals (Basel) 2019; 9: 9. [Medline]

80. Niu D, Wei HJ, Lin L, George H, Wang T, Lee IH, Zhao HY, Wang Y, Kan Y, Shrock E, Lesha E, Wang G, Luo Y, Qing Y, Jiao D, Zhao H, Zhou X, Wang S, Wei H, Güel M, Church GM, Yang L. Inactivation of porcine endogenous retrovirus in pigs using CRISPR-Cas9. Science 2017; 357: 1303-1307. [Medline] [CrossRef]

81. Kobayashi T, Yamaguchi T, Hamanaka S, Kato-Itoh M, Yamazaki Y, Ibata M, Sato H, Lee YS, Usui J, Knisely AS, Hirabayashi M, Nakauchi H. Generation of rat pancreas in mouse by interspecific blastocyst injection of pluripotent stem cells. Cell 2010; 142: 787-799. [Medline] [CrossRef]

82. Matsunari H, Watanabe M, Hasegawa K, Uchikura A, Nakano K, Umeyama $K$, Masaki H, Hamanaka S, Yamaguchi T, Nagaya M, Nishinakamura R, Nakauchi $\mathbf{H}$, Nagashima $\mathbf{H}$. Compensation of disabled organogeneses in genetically modified pig fetuses by blastocyst complementation. Stem Cell Reports 2020; 14: 21-33. [Medline] [CrossRef]

83. Wu J, Platero-Luengo A, Sakurai M, Sugawara A, Gil MA, Yamauchi T, Suzuki K, Bogliotti YS, Cuello C, Morales Valencia M, Okumura D, Luo J, Vilariño M, Parrilla I, Soto DA, Martinez CA, Hishida T, Sánchez-Bautista S, Martinez-Martinez ML, Wang H, Nohalez A, Aizawa E, Martinez-Redondo P, Ocampo A, Reddy P, Roca J, Maga EA, Esteban CR, Bergoren WT, Nuñez Delicado E, Lajara J, Guillen I, Guillen 
P, Campistol JM, Martinez EA, Ross PJ, Izpisua Belmonte JC. Interspecies chimerism with mammalian pluripotent stem cells. Cell 2017; 168: 473-486.e15. [Medline] [CrossRef]

84. Fu R, Yu D, Ren J, Li C, Wang J, Feng G, Wang X, Wan H, Li T, Wang L, Zhang Y, Hai T, Li W, Zhou Q. Domesticated cynomolgus monkey embryonic stem cells allow the generation of neonatal interspecies chimeric pigs. Protein Cell 2020; 11: 97-107. [Medline] [CrossRef]

85. Mehravar M, Shirazi A, Nazari M, Banan M. Mosaicism in CRISPR/Cas9-mediated genome editing. Dev Biol 2019; 445: 156-162. [Medline] [CrossRef]

86. Burkard C, Lillico SG, Reid E, Jackson B, Mileham AJ, Ait-Ali T, Whitelaw CBA, Archibald AL. Precision engineering for PRRSV resistance in pigs: Macrophages from genome edited pigs lacking CD163 SRCR5 domain are fully resistant to both PRRSV genotypes while maintaining biological function. PLoS Pathog 2017; 13: e1006206. [Medline] [CrossRef]

87. Sato M, Kosuke M, Koriyama M, Inada E, Saitoh I, Ohtsuka M, Nakamura S, Sakurai T, Watanabe S, Miyoshi K. Timing of CRISPR/Cas9-related mRNA microinjection after activation as an important factor affecting genome editing efficiency in porcine oocytes. Theriogenology 2018; 108: 29-38. [Medline] [CrossRef]

88. Vera-Rodriguez M, Rubio C. Assessing the true incidence of mosaicism in preimplantation embryos. Fertil Steril 2017; 107: 1107-1112. [Medline] [CrossRef]

89. Vilarino M, Suchy FP, Rashid ST, Lindsay H, Reyes J, McNabb BR, van der Meulen T, Huising MO, Nakauchi H, Ross PJ. Mosaicism diminishes the value of pre-implantation embryo biopsies for detecting CRISPR/Cas9 induced mutations in sheep. Transgenic Res 2018; 27: 525-537. [Medline] [CrossRef]

90. Kondrateva E, Demchenko A, Lavrov A, Smirnikhina S. An overview of currently available molecular Cas-tools for precise genome modification. Gene 2021; 769: 145225. [Medline] [CrossRef]

91. Sakuma T, Ochiai H, Kaneko T, Mashimo T, Tokumasu D, Sakane Y, Suzuki K, Miyamoto T, Sakamoto N, Matsuura S, Yamamoto T. Repeating pattern of non-RVD variations in DNA-binding modules enhances TALEN activity. Sci Rep 2013; 3: 3379. [Medline] [CrossRef]

92. Su X, Chen W, Cai Q, Liang $\mathbf{P}$, Chen Y, Cong P, Huang J. Production of non-mosaic genome edited porcine embryos by injection of CRISPR/Cas9 into germinal vesicle oocytes. J Genet Genomics 2019; 46: 335-342. [Medline] [CrossRef]

93. Onuma A, Fujii W, Sugiura K, Naito K. Efficient mutagenesis by CRISPR/Cas system during meiotic maturation of porcine oocytes. J Reprod Dev 2017; 63: 45-50. [Medline] [CrossRef]

94. Hirata M, Tanihara F, Wittayarat M, Hirano T, Nguyen NT, Le QA, Namula Z, Nii M, Otoi T. Genome mutation after introduction of the gene editing by electroporation of Cas9 protein (GEEP) system in matured oocytes and putative zygotes. In Vitro Cell Dev Biol Anim 2019; 55: 237-242. [Medline] [CrossRef]

95. Tanihara F, Hirata M, Nguyen NT, Le QA, Hirano T, Otoi T. Effects of concentration of CRISPR/Cas9 components on genetic mosaicism in cytoplasmic microinjected porcine embryos. J Reprod Dev 2019; 65: 209-214. [Medline] [CrossRef]

96. Le QA, Hirata M, Nguyen NT, Takebayashi K, Wittayarat M, Sato Y, Namula Z, Nii M, Tanihara F, Otoi T. Effects of electroporation treatment using different concentrations of Cas9 protein with gRNA targeting Myostatin (MSTN) genes on the development and gene editing of porcine zygotes. Anim Sci J 2020; 91: e13386. [Medline] [CrossRef]

97. Wang H, Yang H, Shivalila CS, Dawlaty MM, Cheng AW, Zhang F, Jaenisch R. Onestep generation of mice carrying mutations in multiple genes by CRISPR/Cas-mediated genome engineering. Cell 2013; 153: 910-918. [Medline] [CrossRef]

98. Zhou J, Shen B, Zhang W, Wang J, Yang J, Chen L, Zhang N, Zhu K, Xu J, Hu B, Leng $\mathbf{Q}$, Huang $\mathbf{X}$. One-step generation of different immunodeficient mice with multiple gene modifications by CRISPR/Cas9 mediated genome engineering. Int J Biochem Cell Biol 2014; 46: 49-55. [Medline] [CrossRef]

99. Li W, Teng F, Li T, Zhou Q. Simultaneous generation and germline transmission of multiple gene mutations in rat using CRISPR-Cas systems. Nat Biotechnol 2013; 31: 684-686. [Medline] [CrossRef]

100. Niu Y, Shen B, Cui Y, Chen Y, Wang J, Wang L, Kang Y, Zhao X, Si W, Li W, Xiang AP, Zhou J, Guo X, Bi Y, Si C, Hu B, Dong G, Wang H, Zhou Z, Li T, Tan T, Pu X, Wang F, Ji S, Zhou Q, Huang X, Ji W, Sha J. Generation of gene-modified cynomolgus monkey via Cas9/RNA-mediated gene targeting in one-cell embryos. Cell 2014; 156: 836-843. [Medline] [CrossRef]

101. Wang X, Cao C, Huang J, Yao J, Hai T, Zheng Q, Wang X, Zhang H, Qin G, Cheng J, Wang Y, Yuan Z, Zhou Q, Wang H, Zhao J. One-step generation of triple gene-targeted pigs using CRISPR/Cas9 system. Sci Rep 2016; 6: 20620. [Medline] [CrossRef]

102. Hirata M, Wittayarat M, Namula Z, Le QA, Lin Q, Nguyen NT, Takebayashi K, Sato Y, Tanihara F, Otoi T. Evaluation of multiple gene targeting in porcine embryos by the CRISPR/Cas9 system using electroporation. Mol Biol Rep 2020; 47: 5073-5079. [Medline] [CrossRef]

103. Hirata M, Wittayarat M, Tanihara F, Sato Y, Namula Z, Le QA, Lin Q, Takebayashi $\mathbf{K}$, Otoi T. One-step genome editing of porcine zygotes through the electroporation of a CRISPR/Cas9 system with two guide RNAs. In Vitro Cell Dev Biol Anim 2020; 56: 614-621. [Medline] [CrossRef]

104. Li G, Zhang X, Wang H, Mo J, Zhong C, Shi J, Zhou R, Li Z, Yang H, Wu Z, Liu D. CRISPR/Cas9-mediated integration of large transgene into pig CEP112 Locus. G3 (Bethesda) 2020; 10: 467-473. [Medline] [CrossRef]

105. Xie Z, Jiao H, Xiao H, Jiang Y, Liu Z, Qi C, Zhao D, Jiao S, Yu T, Tang X, Pang D, Ouyang H. Generation of pRSAD2 gene knock-in pig via CRISPR/Cas9 technology. Antiviral Res 2020; 174: 104696. [Medline] [CrossRef]

106. Li L, Meng H, Zou Q, Zhang J, Cai L, Yang B, Weng J, Lai L, Yang H, Gao Y. Establishment of gene-edited pigs expressing human blood-coagulation factor VII and albumin for bioartificial liver use. J Gastroenterol Hepatol 2019; 34: 1851-1859. [Medline] [CrossRef]

107. Zou X, Ouyang H, Yu T, Chen X, Pang D, Tang X, Chen C. Preparation of a new type 2 diabetic miniature pig model via the CRISPR/Cas9 system. Cell Death Dis 2019; 10: 823 [Medline] [CrossRef]

108. Dorado B, Pløen GG, Barettino A, Macías A, Gonzalo P, Andrés-Manzano MJ, González-Gómez C, Galán-Arriola C, Alfonso JM, Lobo M, López-Martín GJ, Molina A, Sánchez-Sánchez R, Gadea J, Sánchez-González J, Liu Y, Callesen H, Filgueiras-Rama D, Ibáñez B, Sørensen CB, Andrés V. Generation and characterization of a novel knockin minipig model of Hutchinson-Gilford progeria syndrome. Cell Discov 2019; 5: 16. [Medline] [CrossRef]

109. Yan S, Tu Z, Liu Z, Fan N, Yang H, Yang S, Yang W, Zhao Y, Ouyang Z, Lai C, Yang H, Li L, Liu Q, Shi H, Xu G, Zhao H, Wei H, Pei Z, Li S, Lai L, Li XJ. A Huntingtin knockin pig model recapitulates features of selective neurodegeneration in Huntington's disease. Cell 2018; 173: 989-1002.e13. [Medline] [CrossRef]

110. Xie F, Zhou X, Lin T, Wang L, Liu C, Luo X, Luo L, Chen H, Guo K, Wei H, Wang Y. Production of gene-edited pigs harboring orthologous human mutations via double cutting by CRISPR/Cas9 with long single-stranded DNAs as homology-directed repair templates by zygote injection. Transgenic Res 2020; 29: 587-598. [Medline] [CrossRef]

111. Mizuno N, Mizutani E, Sato H, Kasai M, Ogawa A, Suchy F, Yamaguchi T, Nakauchi H. Intra-embryo gene cassette knockin by CRISPR/Cas9-mediated genome editing with adeno-associated viral vector. $i$ Science 2018; 9: 286-297. [Medline] [CrossRef]

112. Honda A, Tachibana R, Hamada K, Morita K, Mizuno N, Morita K, Asano M. Efficient derivation of knock-out and knock-in rats using embryos obtained by in vitro fertilization. Sci Rep 2019; 9: 11571. [Medline] [CrossRef]

113. Luo Y, Kofod-Olsen E, Christensen R, Sørensen CB, Bolund L. Targeted genome editing by recombinant adeno-associated virus ( $\mathrm{rAAV}$ ) vectors for generating genetically modified pigs. J Genet Genomics 2012; 39: 269-274. [Medline] [CrossRef]

114. Montag J, Petersen B, Flögel AK, Becker E, Lucas-Hahn A, Cost GJ, Mühlfeld C, Kraft T, Niemann H, Brenner B. Successful knock-in of hypertrophic cardiomyopathymutation R723G into the MYH7 gene mimics HCM pathology in pigs. Sci Rep 2018; 8: 4786. [Medline] [CrossRef]

115. Zhu XX, Zhong YZ, Ge YW, Lu KH, Lu SS. CRISPR/Cas9-mediated generation of Guangxi Bama minipigs harboring three mutations in $\alpha$-synuclein causing Parkinson's disease. Sci Rep 2018; 8: 12420. [Medline] [CrossRef]

116. Li W, Shi L, Zhuang Z, Wu H, Lian M, Chen Y, Li L, Ge W, Jin Q, Zhang Q, Zhao Y, Liu Z, Ouyang Z, Ye Y, Li Y, Wang H, Liao Y, Quan L, Xiao L, Lai L, Meng G, Wang K. Engineered pigs carrying a gain-of-function NLRP3 homozygous mutation can survive to adulthood and accurately recapitulate human systemic spontaneous inflammatory responses. J Immunol 2020; 205: 2532-2544. [Medline] [CrossRef]

117. Yang Y, Wang K, Wu H, Jin Q, Ruan D, Ouyang Z, Zhao B, Liu Z, Zhao Y, Zhang Q, Fan N, Liu Q, Guo S, Bu L, Fan Y, Sun X, Li X, Lai L. Genetically humanized pigs exclusively expressing human insulin are generated through custom endonucleasemediated seamless engineering. J Mol Cell Biol 2016; 8: 174-177. [Medline] [CrossRef]

118. Liu M, Rehman S, Tang X, Gu K, Fan Q, Chen D, Ma W. Methodologies for improving HDR efficiency. Front Genet 2019; 9: 691. [Medline] [CrossRef]

119. Ray U, Raghavan SC. Modulation of DNA double-strand break repair as a strategy to improve precise genome editing. Oncogene 2020; 39: 6393-6405. [Medline] [CrossRef]

120. Komor AC, Kim YB, Packer MS, Zuris JA, Liu DR. Programmable editing of target base in genomic DNA without double-stranded DNA cleavage. Nature 2016; 533: 420-424. [Medline] [CrossRef]

121. Gaudelli NM, Komor AC, Rees HA, Packer MS, Badran AH, Bryson DI, Liu DR. Programmable base editing of $\mathrm{A} \bullet \mathrm{T}$ to $\mathrm{G} \cdot \mathrm{C}$ in genomic DNA without DNA cleavage. Nature 2017; 551: 464-471. [Medline] [CrossRef]

122. Wang Y, Bi D, Qin G, Song R, Yao J, Cao C, Zheng Q, Hou N, Wang Y, Zhao J. Cytosine base editor (hA3A-BE3-NG)-mediated multiple gene editing for pyramid breeding in pigs. Front Genet 2020; 11: 592623. [Medline] [CrossRef]

123. Xie J, Ge W, Li N, Liu Q, Chen F, Yang X, Huang X, Ouyang Z, Zhang Q, Zhao Y, Liu Z, Gou S, Wu H, Lai C, Fan N, Jin Q, Shi H, Liang Y, Lan T, Quan L, Li X, Wang $\mathbf{K}$, Lai L. Efficient base editing for multiple genes and loci in pigs using base editors. Nat Commun 2019; 10: 2852. [Medline] [CrossRef]

124. Molla KA, Yang Y. CRISPR/Cas-mediated base editing: technical considerations and 
practical applications. Trends Biotechnol 2019; 37: 1121-1142. [Medline] [CrossRef]

125. Tan W, Carlson DF, Lancto CA, Garbe JR, Webster DA, Hackett PB, Fahrenkrug SC. Efficient nonmeiotic allele introgression in livestock using custom endonucleases. Proc Natl Acad Sci USA 2013; 110: 16526-16531. [Medline] [CrossRef]

126. Kang JT, Ryu J, Cho B, Lee EJ, Yun YJ, Ahn S, Lee J, Ji DY, Lee K, Park KW. Generation of RUNX3 knockout pigs using CRISPR/Cas9-mediated gene targeting. Reprod Domest Anim 2016; 51: 970-978. [Medline] [CrossRef]

127. Shen Y, Xu K, Yuan Z, Guo J, Zhao H, Zhang X, Zhao L, Qing Y, Li H, Pan W, Jia B, Zhao HY, Wei HJ. Efficient generation of P53 biallelic knockout Diannan miniature pigs via TALENs and somatic cell nuclear transfer. $J$ Transl Med 2017; 15: 224. [Medline] [CrossRef]

128. Matsunari H, Honda M, Watanabe M, Fukushima S, Suzuki K, Miyagawa S, Nakano K, Umeyama K, Uchikura A, Okamoto K, Nagaya M, Toyo-Oka T, Sawa Y, Nagashima H. Pigs with $\delta$-sarcoglycan deficiency exhibit traits of genetic cardiomyopathy. Lab Invest 2020; 100: 887-899. [Medline] [CrossRef]

129. Cho B, Kim SJ, Lee EJ, Ahn SM, Lee JS, Ji DY, Lee K, Kang JT. Generation of insulin-deficient piglets by disrupting INS gene using CRISPR/Cas9 system. Transgenic Res 2018; 27: 289-300. [Medline] [CrossRef]

130. Yu HH, Zhao H, Qing YB, Pan WR, Jia BY, Zhao HY, Huang XX, Wei HJ. Porcine zygote injection with Cas9/sgRNA results in DMD-modified pig with muscle dystrophy. Int J Mol Sci 2016; 17: 17. [Medline] [CrossRef]

131. Huang L, Hua Z, Xiao H, Cheng Y, Xu K, Gao Q, Xia Y, Liu Y, Zhang X, Zheng X, Mu Y, Li K. CRISPR/Cas9-mediated ApoE-/- and LDLR-/- double gene knockout in pigs elevates serum LDL-C and TC levels. Oncotarget 2017; 8: 37751-37760. [Medline] [CrossRef]

132. Wang X, Zhou J, Cao C, Huang J, Hai T, Wang Y, Zheng Q, Zhang H, Qin G, Miao X, Wang H, Cao S, Zhou Q, Zhao J. Efficient CRISPR/Cas9-mediated biallelic gene disruption and site-specific knockin after rapid selection of highly active sgRNAs in pigs. Sci Rep 2015; 5: 13348. [Medline] [CrossRef]

133. Hai T, Guo W, Yao J, Cao C, Luo A, Qi M, Wang X, Wang X, Huang J, Zhang Y, Zhang H, Wang D, Shang H, Hong Q, Zhang R, Jia Q, Zheng Q, Qin G, Li Y, Zhang T, Jin W, Chen ZY, Wang H, Zhou Q, Meng A, Wei H, Yang S, Zhao J. Creation of miniature pig model of human Waardenburg syndrome type $2 \mathrm{~A}$ by ENU mutagenesis. Hum Genet 2017; 136: 1463-1475. [Medline] [CrossRef]

134. Chen J, An B, Yu B, Peng X, Yuan H, Yang Q, Chen X, Yu T, Wang L, Zhang X, Wang H, Zou X, Pang D, Ouyang H, Tang X. CRISPR/Cas9-mediated knockin of human factor IX into swine factor IX locus effectively alleviates bleeding in hemophilia B pigs. Haematologica 2021; 106: 829-837. [Medline]

135. Quadalti C, Brunetti D, Lagutina I, Duchi R, Perota A, Lazzari G, Cerutti R, Di Meo I, Johnson M, Bottani E, Crociara P, Corona C, Grifoni S, Tiranti V, FernandezVizarra E, Robinson AJ, Viscomi C, Casalone C, Zeviani M, Galli C. SURF1 knockout cloned pigs: Early onset of a severe lethal phenotype. Biochim Biophys Acta Mol Basis Dis 2018; 1864(6 Pt A): 2131-2142. [Medline] [CrossRef]

136. Umeyama K, Watanabe K, Watanabe M, Horiuchi K, Nakano K, Kitashiro M, Matsunari H, Kimura T, Arima Y, Sampetrean O, Nagaya M, Saito M, Saya H, Kosaki K, Nagashima H, Matsumoto M. Generation of heterozygous fibrillin-1 mutant cloned pigs from genome-edited foetal fibroblasts. Sci Rep 2016; 6: 24413. [Medline] [CrossRef]

137. Matsunari H, Watanabe M, Nakano K, Enosawa S, Umeyama K, Uchikura A, Yashima S, Fukuda T, Klymiuk N, Kurome M, Kessler B, Wuensch A, Zakhartchenko V, Wolf E, Hanazono Y, Nagaya M, Umezawa A, Nakauchi H, Nagashima H. Modeling lethal X-linked genetic disorders in pigs with ensured fertility. Proc Natl Acad Sci USA 2018; 115: 708-713. [Medline] [CrossRef]

138. Yao J, Huang J, Hai T, Wang X, Qin G, Zhang H, Wu R, Cao C, Xi JJ, Yuan Z, Zhao
J. Efficient bi-allelic gene knockout and site-specific knock-in mediated by TALENs in pigs. Sci Rep 2014; 4: 6926. [Medline] [CrossRef]

139. Zhou X, Xin J, Fan N, Zou Q, Huang J, Ouyang Z, Zhao Y, Zhao B, Liu Z, Lai S, Yi X, Guo L, Esteban MA, Zeng Y, Yang H, Lai L. Generation of CRISPR/Cas9mediated gene-targeted pigs via somatic cell nuclear transfer. Cell Mol Life Sci 2015; 72: 1175-1184. [Medline] [CrossRef]

140. Koppes EA, Redel BK, Johnson MA, Skvorak KJ, Ghaloul-Gonzalez L, Yates ME, Lewis DW, Gollin SM, Wu YL, Christ SE, Yerle M, Leshinski A, Spate LD, Benne JA, Murphy SL, Samuel MS, Walters EM, Hansen SA, Wells KD, Lichter-Konecki U, Wagner RA, Newsome JT, Dobrowolski SF, Vockley J, Prather RS, Nicholls RD. A porcine model of phenylketonuria generated by CRISPR/Cas9 genome editing. JCI Insight 2020; 5 .

141. He J, Li Q, Fang S, Guo Y, Liu T, Ye J, Yu Z, Zhang R, Zhao Y, Hu X, Bai X, Chen X, Li N. PKD1 mono-allelic knockout is sufficient to trigger renal cystogenesis in a mini-pig model. Int J Biol Sci 2015; 11: 361-369. [Medline] [CrossRef]

142. Watanabe M, Nakano K, Matsunari H, Matsuda T, Maehara M, Kanai T, Kobayashi M, Matsumura Y, Sakai R, Kuramoto M, Hayashida G, Asano Y, Takayanagi S, Arai Y, Umeyama K, Nagaya M, Hanazono Y, Nagashima H. Generation of interleukin-2 receptor gamma gene knockout pigs from somatic cells genetically modified by zinc finger nuclease-encoding mRNA. PLoS One 2013; 8: e76478. [Medline] [CrossRef]

143. Kang JT, Cho B, Ryu J, Ray C, Lee EJ, Yun YJ, Ahn S, Lee J, Ji DY, Jue N, ClarkDeener S, Lee K, Park KW. Biallelic modification of IL2RG leads to severe combined immunodeficiency in pigs. Reprod Biol Endocrinol 2016; 14: 74. [Medline] [CrossRef]

144. Chen B, Gu P, Jia J, Liu W, Liu Y, Liu W, Xu T, Lin X, Lin T, Liu Y, Chen H, Xu M, Yuan J, Zhang J, Zhang Y, Xiao D, Gu W. Optimization strategy for generating gene-edited Tibet minipigs by synchronized oestrus and cytoplasmic microinjection. Int $J$ Biol Sci 2019; 15: 2719-2732. [Medline] [CrossRef]

145. Ren J, Yu D, Fu R, An P, Sun R, Wang Z, Guo R, Li H, Zhang Y, Li Z, Yang YG, Li W, Hai T, Hu Z. IL2RG-deficient minipigs generated via CRISPR/Cas9 technology support the growth of human melanoma-derived tumours. Cell Prolif 2020; 53: e12863. [Medline] [CrossRef]

146. Wang Y, Du Y, Zhou X, Wang L, Li J, Wang F, Huang Z, Huang X, Wei H. Efficien generation of B2m-null pigs via injection of zygote with TALENs. Sci Rep 2016; 6 38854. [Medline] [CrossRef]

147. Park KE, Kaucher AV, Powell A, Waqas MS, Sandmaier SE, Oatley MJ, Park CH, Tibary A, Donovan DM, Blomberg LA, Lillico SG, Whitelaw CB, Mileham A, Telugu BP, Oatley JM. Generation of germline ablated male pigs by CRISPR/Cas9 editing of the NANOS2 gene. Sci Rep 2017; 7: 40176. [Medline] [CrossRef]

148. Wu J, Vilarino M, Suzuki K, Okamura D, Bogliotti YS, Park I, Rowe J, McNabb B, Ross PJ, Belmonte JCI. CRISPR-Cas9 mediated one-step disabling of pancreatogenesis in pigs. Sci Rep 2017; 7: 10487. [Medline] [CrossRef]

149. Xiang G, Ren J, Hai T, Fu R, Yu D, Wang J, Li W, Wang H, Zhou Q. Editing porcine IGF2 regulatory element improved meat production in Chinese Bama pigs. Cell Mol Life Sci 2018; 75: 4619-4628. [Medline] [CrossRef]

150. Whitworth KM, Rowland RRR, Petrovan V, Sheahan M, Cino-Ozuna AG, Fang Y, Hesse R, Mileham A, Samuel MS, Wells KD, Prather RS. Resistance to coronavirus infection in amino peptidase N-deficient pigs. Transgenic Res 2019; 28: 21-32. [Medline] [CrossRef]

151. Tu CF, Chuang CK, Hsiao KH, Chen CH, Chen CM, Peng SH, Su YH, Chiou MT, Yen CH, Hung SW, Yang TS, Chen CM. Lessening of porcine epidemic diarrhoea virus susceptibility in piglets after editing of the CMP-N-glycolylneuraminic acid hydroxylase gene with CRISPR/Cas9 to nullify N-glycolylneuraminic acid expression. PLoS One 2019; 14: e0217236. [Medline] [CrossRef] 